\title{
A STUDY ON IMPACT OF POVERTY ALLEVIATION PROGRAMS ON SKILL DEVELOPMENT OF TRIBAL WOMEN HOUSEHOLDS IN TELANGANA STATE
}

\author{
Pacha Malyadri ${ }^{1}$ and Kankipati Srinivasa Rao $^{2}$ \\ ${ }^{1}$ ICSSR Senior Fellow, Centre for Economic and Social Studies, Hyderabad, India \\ Email: drpm16@gmail.com \\ ${ }^{2}$ Associate Professor of Commerce \& Management, \\ Vivek Vardhini College of P.G Studies, Hyderabad, India \\ Email: srikanrao2006@gmail.com
}

\begin{abstract}
Tribal women are fifty percent of tribal population. However, tribal women are exclusion, vulnerable and in-accessible to the poverty schemes targeted for their well-being. The main objective of this study is to determine the utilization pattern of poverty alleviation programs and its impact on satisfaction level of tribal women. As per the methodology of the study, primary data had been collected from tribal women perception on awareness of poverty alleviation programs. The primary data was analyzed by using statistical tools like one-way ANOVA and regression analysis. The results of this study indicated that age group had an impact on tribal women empowerment. The literacy rate is also increasing and poverty is consistently declining among tribal women with poverty alleviation and skill development programs implemented by government in Telangana State.
\end{abstract}

Key words: Tribal Women Welfare, Poverty Alleviation Programs, Skill Development.

\section{Introduction}

Empowerment of tribal women had become an important concern for overall wellbeing of the society. Government had been developing strategies for poverty alleviation among the tribal women. In this present paper the empowerment of tribal women with implementation of various poverty alleviation programs had been made with empirical investigation. The Government of India declared the year 2001 as 'Women's Empowerment Year' and a lot has been and is being done at national and international levels since then. Women empowerment is an active process enabling women to realize their full identity and power in all spheres of life and tribal women is not an exception. (Gnanadhas et al, 2011). Eradication of poverty remains a major challenge of planned economic development. Experiences of different states with economic growth and poverty reduction have been so varied that it is difficult to offer any general policy prescription. There are states that followed the path of high agricultural growth and succeeded in reducing poverty (Punjab and Haryana) and states that focused on human resource development and reduced poverty (Kerala). There have been states that implemented land reforms with vigour, empowered the panchayats, mobilized the poor and implemented poverty-alleviation programs effectively (West Bengal) and states that brought about reduction in poverty by direct public intervention in the form of public distribution of food grains (Andhra Pradesh). The Mission for Elimination of Poverty in Municipal Areas (MEPMA) is a Government of Telangana Society forming part of Department of Municipal Administration \& Urban Development. Poverty alleviation programs targeted for tribal women still to reach many pockets to accomplish desired goals for sustainable development.

\section{Poverty Alleviation Programs}

Land distribution welfare scheme of the government that provides 3 acres of agricultural land to landless ST women, along with the provision for creation of irrigation facilities, land development and other agricultural inputs for their sustainable livelihood. Government distributed 2,524 acres of land to 959 Dalits spending Rs.94 crore in the first year. Special Central Assistance to Tribal Sub-Scheme (SCA to TSS) is 100\% grant from Government of India (since 1977-78). It is charged to Consolidated Fund of India (except grants for North Eastern States, a voted item) and is an additive to State Plan funds and efforts for Tribal Development. This grant is utilized for economic development of Integrated Tribal Development Project (ITDP), Integrated Tribal Development Agency (ITDA), Modified Area 
Development Approach (MADA), Clusters, Particularly Vulnerable Tribal Groups (PVTGs) and dispersed tribal population. The pre-matric scholarships, post-matric scholarships, fellowship schemes for ST students, central sector scheme, grant-in-aid and vocational training are provided to tribal people and majority of these programs provide assistance to tribal women. The wellbeing of SC and ST tribal women is ensured by both the state and central government by allocating funds for various programs such as;

- Institutional Support for Development \& Marketing of Tribal Products / Produce (Central Sector Scheme)

- Mechanism for Marketing of Minor Forest Produce (MFP) through Minimum Support Price (MSP) and Development of Value Chain for MFP' as a measure of social safety for MFP gatherers

- Fellowship (earlier known as RGNF) scheme for st students

- Scheme of Strengthening Education among ST Girls in Low Literacy Districts

- Scheme of Grant-in-aid to voluntary organizations working for the welfare of Scheduled Tribes

- Vocational Training in Tribal Areas

- Support to Tribal Research Institutes (TRIs) and Tribal Festivals, Research Information and Mass Education;

The above poverty alleviation programs targeted to bring change in the lives of tribal women. However the awareness, implementation, its impact, perception and the scale of skills has to be monitored time to time for taking necessary steps for further effectiveness skill development through poverty alleviation programs. The present study is focused in that direction. Keeping in view the problem and to draw the inferences from the designed objectives the following available review of literature has gone through to find out the gaps.

\section{Literature Review}

Reddy et al (2016) had explained that structural changes have been taking with many poverty alleviation programs launched by both central and state governments in India. Dokur village in Telangana state had transformed and introduced green revolution technologies. Initially government had considered about alleviation of poverty and later started assisted rural people by providing investment for agriculture and farming. Lal (2016) had mentioned that dimensions of women empowerment are cultural, political, social and economic. Educational facilities are to be improved in the tribal areas to eradicate illiteracy. In this context, government schools should be strengthened as tribal children mostly depend on them, school drop outs be discouraged through incentives and by creating interest in education. Discrimination between sons and daughter should be reduced through counseling.

Pawar (2016) had argued that existing banking system could not lead to the development of weaker sections of the society. The tribal population in the State of Telangana and in the country as a whole is the most deprived and vulnerable community that faces severe economic exclusion. Although certain constitutional safeguards are provided, there has been no economic, Social and political mobility across these communities. Majority of the population approximately 74 percent are residing in rural areas and most of them belong to weaker sections of the society. Gangadhar et al (2017) had found through empirical investigation that microfinance programs had improved health awareness among rural women. The participation microfinance programs had improved the economic condition of tribal women in Karimnagar district of Telangana state. Vadlakonda (2017) had explained that poverty of rural women had been avoided to a large extent with Indira Kranthi Patakam in Telangana. The self-help groups (SHG) groups were established only in the rural areas with one or more groups were formed with rural poor women. The groups were usually responsive to a perceived need. Such groups have been formed around a specific productive activity and often they have promoted savings among their members and used the pooled resources to meet the emergency needs of the members of the group including consumption needs. Malothu (n.d) had explained that Self Help Groups (SHGs) have great importance in the process of participatory development and empowerment of women. Women SHGs in Telangana have become successful in bringing the tribal women in the main stream of decision making. SHGs are also a feasible organized setup to expand micro credit to the rural tribal women in Telangana and encourage them to enter into entrepreneurial ventures. 


\section{Research Gap}

Majority of the studies revealed that the investments on agriculture and farming productive activity, micro credit facilities to the rural tribal for promotion savings and how the size of tribal participation in microfinance programs and also focused on the economic exclusions of tribal. However impact of poverty alleviation programs, utilization pattern, and implementation of schemes were not focused with this background the researcher taken up the present study to find out ground realities.

\section{Objectives of the Study}

- To examine the utilization pattern of poverty alleviation programs by tribal women.

- To study the impact of poverty alleviation programs on satisfaction level of tribal women.

- To analyze the various poverty alleviation programs implemented by Government.

\section{Methodology}

Primary data had been collected from tribal women. The women participated in the survey are also members of self-help groups in Warangal district in Telangana State. The sample size of the study is 130 and combination of convenient and snowballing sampling methods had been used for selecting the respondents to the study. The data had been collected through closed ended questionnaire and the questions were translated into local language and the responses are marked on the measurement scale. The first part of the questionnaire collected demographic profile of the respondents and the second part consists of items which are measured on five-point Likert type scale. The statistical tools like ANOVA, regression and descriptive statistics have been used for data analysis. SPSS software had been used for data analysis.

\section{Analysis of Data}

Among the total respondents 24.60 percent belong to ' 18 to 25 Years' age group, 36.90 percent belong to '26 to 35 Years' age group, 24.60 percent belong to ' 35 to 45 Years' age group and 13.80 percent belong to 'Above 45 Years' age group. From the perspective of literacy, 20.80 percent of respondents are illiterates, 24.60 percent have completed primary level education, 36.90 percent completed secondary level education and 17.70 percent have completed above SSC level education. Majority of the respondents i.e. 83 percent are married and 17 percent are unmarried. It is also found that in majority of home women is decision maker. Among the respondents 23.10 percent of respondents have mentioned husband takes decision, 50.80 percent of respondents stated that wife (woman) takes decision, 12.30 percent have stated that son(s) takes decision and 13.80 have stated that daughter(s) takes decision. From the dimension of occupation, 27.70 of the respondents are into agriculture, 35.40 percent of respondents are into agriculture based labor, 12.1 percent of respondents are self-employed and 24.8 percent are into non-agriculture based labor. The means for the variables awareness, satisfaction, SHGs and women empowerment are 3.98, 4.12, 4.23 and 4.10 respectively.

$\mathrm{H} 1$ : There is an association between age group and satisfaction towards poverty alleviation programs.

$\mathrm{H} 1$ is accepted because $\mathrm{p}$-value in Table 1 is less than 0.05 . Hence there is an association between age group and satisfaction level of employees towards poverty alleviation programs.

Table 01: One-way ANOVA with Age Group

\begin{tabular}{|l|l|r|r|r|r|r|}
\hline Variables & $\begin{array}{c}\text { Sum of } \\
\text { Squares }\end{array}$ & df & Mean Square & F & $\begin{array}{c}\text { Sig. } \\
\text { (p-value) }\end{array}$ \\
\hline \multirow{3}{*}{ Satisfaction } & Between Groups & 18.848 & 3 & 6.283 & 19.677 & 0.000 \\
\cline { 2 - 7 } & Within Groups & 40.229 & 126 & 0.319 & & \\
\cline { 2 - 7 } & Total & 59.077 & 129 & & & \\
\hline \multirow{3}{*}{ Empowerment } & Between Groups & 6.242 & 3 & 2.081 & 3.964 & 0.010 \\
\cline { 2 - 8 } & Within Groups & 66.135 & 126 & 0.525 & & \\
\cline { 2 - 8 } & Total & 72.377 & 129 & & & \\
\hline
\end{tabular}

Source: SPSS Output

$\mathrm{H} 2$ : There is an association between women empowerment and age group of the respondents. $\mathrm{H} 2$ is accepted because the value in Table 1 is less than 0.05 therefore there is an association between women empowerment and age group of the respondents. 
Table 02: Regression Coefficients ${ }^{a}$

\begin{tabular}{|c|c|c|c|c|c|c|}
\hline \multicolumn{2}{|c|}{ Model } & \multirow{2}{*}{\multicolumn{2}{|c|}{ Unstandardized Coefficients }} & \multirow{2}{*}{$\begin{array}{c}\text { Standardized } \\
\text { Coefficients } \\
\text { Beta }\end{array}$} & $t$ & $\begin{array}{c}\text { Sig. } \\
\text { (p-value) }\end{array}$ \\
\hline & & & & & & \\
\hline \multirow{4}{*}{1} & (Constant) & 1.403 & 0.552 & & 2.543 & 0.012 \\
\hline & Awareness on schemes & 0.242 & 0.106 & 182 & 2.273 & 0.025 \\
\hline & Satisfaction & 0.021 & 0.088 & 00.019 & 0.238 & 0.812 \\
\hline & $\begin{array}{l}\text { Perception towards Poverty } \\
\text { alleviation proarammes }\end{array}$ & 0.407 & 0.061 & 0.509 & 6.669 & 0.000 \\
\hline
\end{tabular}

Source: SPSS Output

a. Dependent Variable: Empowerment

$\mathrm{H} 3$ : There is an impact of awareness on schemes and tribal women empowerment.

$\mathrm{H} 3$ is rejected because $\mathrm{p}$-value in Table 2 is more than 0.05 . Hence there is no significant relationship between awareness of various schemes and women empowerment.

$\mathrm{H} 4$ : There is an impact of satisfaction and perception towards tribal women empowerment.

$\mathrm{H} 4$ is rejected because $\mathrm{p}$-value in Table 2 is more than 0.05 . Hence there is no association between satisfaction and women empowerment.

H5: There is an impact on perception towards poverty alleviation programmes and tribal women empowerment.

$\mathrm{H} 5$ is accepted because $\mathrm{p}$-value in Table 2 is less than 0.05 . Hence there is an impact of perception towards poverty alleviation programs on women empowerment.

\section{Suggestions}

- Illiteracy is the main problem for un-awareness of the poverty alleviation programs. Therefore more tribal schools may be established. Once tribal women undergo education they can concentrate more on skill development programmes

- Training has to be provided for tribal women on concurrent basis in executing the programs/schemes time to time.

- Skill enhancement camps are to be deeply organized for tribal women so as to get success of poverty alleviation programs

- An advisory team may be set up for designing and monitoring poverty alleviation programs comprising a successful poor tribal women entrepreneur in the team.

- To continue poverty reduction and empowerment projects for a minimum span of 10-15 years so as to achieve desired results.

\section{Discussion and Conclusion}

It is evident from this study that both central and state government had implemented various poverty alleviation programs in Telangana State. The programs had helped tribal women for completing the education, investment for agriculture, land distribution for agriculture and financial assistance for self-employment. A separate ministry had been established for welfare of tribal women and assisting them in all ways so that women empowerment takes place. It is found from this empirical survey that there is awareness, satisfaction and perception towards poverty alleviation programs is high among the tribal women. The women empowerment had taken place with effective implementation of poverty alleviation programs. The following are some of the suggestions may be taken into consideration for the effective implementation of tribal women for their further empowerment.

\section{Future Research}

There is a scope to conduct an empirical study for future research in terms of income generation activities, asset accumulation and also the scale of skill enhancement before and after the availing the Poverty alleviation programs by tribal women in all the tribal pockets in the state of Telangana and other states having more tribal population.

\section{References}

1. Andhra Pradesh. Acharya NG Ranga Agricultural University, Rajendranagar, Hyderabad,

2. Assari, S. (2018). Life expectancy gain due to employment status depends on race, gender, education, and their intersections. Journal of Racial and Ethnic Health Disparities, 5(2), 375- 386. https://doi.org/10.1007/s40615-017-0381-x 
3. Atchoarena, D. \& Gasperini, L. (2003) Education for rural development: towards new policy responses. FAO, UNESCO

4. Gangadhar, S., Bhat, M. S., \& Malyadri, P. (2017).An Empirical Study on Microfinance and Women Empowerment in Karimnagar District of Telangana State, India. CS Canada International Business and Management, 14(2), 65-69.

5. Gnanadhas, Edwin \& Mahalekshmi, M. (2011).Micro Finance and Self-Help-Groups. New Delhi: Discovery Publishing House

6. Lal, B. S. (2016). Economic Empowerment of Tribal Women: A Study in Telangana State. Social Sciences International Research Journal, 2, 407-415.

7. Pallavi, Inupanuri (2006). A study on empowerment of tribal women in Khammam district of

8. Pawar, I. A. (2016).Impact of Microfinance on Tribal Development in Telangana. Sumedha Journal of Management, 5(2), 35.

9. Reddy, A. A., Rani, C. R., Cadman, T., Reddy, T. P., Battarai, M., \& Reddy, A. N. (2016).Rural Transformation of a Village in Telangana, a Study of Dokur since 1970s. International Journal of Rural Management, 12(2), 143-178.

10. Swamy, G. A., Rao, K. V., \& Reddy, V. N. (2016). The Impact of SHG Model on Chenchu Tribal Women in Andhra Pradesh. South Asian Journal of Participative Development, 16(2), 55.

11. Vadlakonda, S (.n.d) (2017) The Impact of Indira Kranthi Pathakam (IKP) in Rural Women in Telangana: A study.

12. World Bank Group study: (2003) Public Policy for Corporate Social Responsibility Edited by Djordjija Petkoski World Bank Institute and Nigel Twose World Bank Group 